\title{
IMPORTANŢA DIAGNOSTICULUI ETIOLOGIC ÎN INFECT,IILE VIRALE SEVERE ALE TRACTULUI RESPIRATOR INFERIOR LA SUGAR ŞI COPIL
}

\author{
Asist. Univ. Dr. Alexandru-Ioan Ulmeanu ${ }^{1,2}$, Şef Lucr. Dr. Carmen Zăpucioiu ${ }^{1,2}$, \\ Dr. Maria Dorina Crăciun ${ }^{1}$, Prof. Dr. Coriolan Ulmeanu ${ }^{1,2}$ \\ ${ }^{1}$ Spitalul Clinic de Urgență pentru Copii ,, Grigore Alexandrescu“, Bucureşti \\ ${ }^{2}$ Catedra Pediatrie, Universitatea de Medicină şi Farmacie ,, Carol Davila“, Bucureşti
}

\begin{abstract}
REZUMAT
Introducere. Pneumonia comunitară reprezintă una din cauzele principale de deces în lume la copii cu vârsta sub 5 ani. Detecția virală prin PCR multiplex este din ce în ce mai utilizată în practică; ea este utilă pentru a înțelege epidemiologia şi impactul virusurilor asupra populației pediatrice, însă există în continuare multe discuții legate de modul în care detecția virală influențează modul efectiv de îngrijire al pacientului.

Obiective. În studiul efectuat ne-am propus analiza impactului pe care l-a avut identificarea etiologiei virale asupra duratei spitalizării şi asupra tratamentului administrat pe parcursul internării în spital.

Material şi metodă. Am efectuat un studiu retrospectiv pe o perioadă de 4 ani, au fost selectați copii între $0-5$ ani cu infecție severă de tract respirator inferior. Am comparat 3 grupuri: un grup cu infecție virală specificată, un grup cu infecție virală nespecificată şi un grup cu infecție bacteriană.

Rezultate. În perioada analizată 72 de copii ce au prezentat semne de insuficiență respiratorie acută au avut stabilit un diagnostic etiologic concret de infecție virală, doar $2 \%$ din totalul infecțiilor virale diagnosticate în spital. Etiologia principală a fost reprezentată de virusul sincițial respirator (VSR) în $73,5 \%$ dintre cazuri, urmat de Influenza cu 11\%, Parainfluenza cu 4,2\%, Metapneumovirusul (HMPV), Rinovirus, Bocavirus şi Adenovirus, toate cu 2,8\%. În cadrul infecției virale nespecificate s-au folosit antibiotice în $85,5 \%(n=53)$ dintre cazuri. În cadrul infecției virale specificate, deşi etiologia virală a fost certă, rata de folosire a antibioticelor a fost mai ridicată de $92 \%(n=57)$ Durata spitalizării a fost în medie de cu 2,5 zile mai lungă în cadrul lotului cu infecție virală specificată, față de lotul cu infecție virală nespecificată. Deşi diagnosticul de infecție virală a fost cert, dat fiind tabloul clinic sever şi vârsta mică a copiilor, cheltuielile realizate pentru cei cu infecție virală specificată au fost cu $30 \%$ mai mari față de cei cu infecție virală nespecificată.

Concluzii. În studiul efectuat VSR este virusul cel mai frecvent implicat în etiologia ITRI virale, fiind implicat în forme severe de boală mai ales la sugarii mici şi foştii prematuri. Antibioterapia este utilizată în mod frecvent în formele severe de ITRI, chiar dacă etiologia virală este certă şi cunoscută, clasele de antibiotice folosite fiind asemănătoare. Determinarea etiologiei virale nu a redus spitalizarea şi nici nu a dus la schimbarea atitudinii terapeutice a medicului curant.
\end{abstract}

Cuvinte cheie: pneumonie, bronşiolită, pneumonie virală, costuri spitalizare, antibioterapie

\section{INTRODUCERE}

Pneumonia comunitară reprezintă una din cauzele principale de deces în lume la copii cu vârsta sub 5 ani. (1) OMS estimează că există în fiecare an 156 de milioane de cazuri de pneumonie la această grupă de vârstă, mai mult de jumătate din cazuri fiind raportate în țări în curs de dezvoltare. (2) Dintre acestea, mai mult de $50 \%$ dintre cazuri necesită spitalizare, iar 20\% prezintă forme foarte severe de boală. (3) Diagnosticul etiologic rămâne în continuare dificil de stabilit, în ultimii ani însă rata de detecție a virusurilor şi a pneumococului în cadrul infecțiilor de tract respirator inferior (ITRI) s-a îmbunătățit considerabil prin tehnici de imunofluorescență indirectă, ELISA şi PCR efectuate din aspiratele nazofaringiene ale copiilor. (4-5) În practică detecția virală prin PCR multiplex este din ce în ce mai utilizată; ea este foarte utilă pentru a înțelege epidemiologia şi impactul virusurilor asupra populaţiei pediatrice, însă există în continuare multe discuții legate de impactul detecției virale asupra modului efectiv de îngrijire al pacientului. (6) 


\section{OBIECTIVE}

În studiul efectuat ne-am propus analiza impactului pe care 1-a avut identificarea etiologiei virale asupra duratei spitalizării şi asupra tratamentului administrat pe parcursul internării în spital. Ca obiectiv secundar ne-am propus compararea ITRI severe de etiologie virală cu ITRI severe de etiologie bacteriană la copii cu vârsta cuprinsă între 0-5 ani urmărind parametrii anamnestici, clinici, paraclinici precum şi tratamentul administrat.

\section{MATERIAL ŞI METODĂ}

Am efectuat un studiu retrospectiv pe o perioadă de 4 ani între aprilie 2011 şi aprilie 2015 pe pacienți internați şi tratați în SCUC „Grigore Alexandrescu“", Bucureşti. Criteriul principal de selecție a fost: copii între 0-5 ani cu infecție severă de tract respirator inferior. Au fost selectați numai pacienții ce aveau diagnostic secundar de insuficiență respiratorie. Am analizat 3 grupuri de pacienți: un grup cu infecție virală specificată (copii cu diagnostic de pneumonie sau bronşiolită la care s-au realizat determinări virale prin RT-PCR şi teste rapide multiplex, de gripă sau virus sincițial respirator), un grup cu infecție virală nespecificată (copii ce aveau diagnostic la externare de pneumonie sau bronşiolită, infecția virală fiind nespecificată, aceasta fiind suţinută de criterii clinice şi paraclinice) şi un grup cu infecție bacteriană (copii ce aveau diagnostic de infecție bacteriană aceasta fiind susținută de criterii clinice şi paraclinice). Am exclus din studiu: copii cu infecție virală complicată pe parcursul internării cu suprainfecție bacteriană, copii cu boli neuromusculare, boli congenitale de cord şi imunodeficiențe, copii cu infecție bacteriană complicată cu abces, pleurezie, empiem, sepsis sau meningită. Au fost analizate foile de observație, epicrizele, deconturile şi datele din programul statistic informatic Hipocrate. Am analizat datele cu ajutorul pachetului de programe Microsoft Office 2010 şi SpSS v20. Am folosit pentru analiza asocierilor statistice testul $\mathrm{t}$ student pentru variabilele continue, odds ratio şi Fischer exact test pentru variabilele nominale, considerând asocierile obținute cu p $<0,05$ semnificative statistic.

\section{REZULTATE ŞI DISCUȚII}

În perioada analizată s-au înregistrat 39.969 de internări în clinica de Pediatrie a SCUC „Grigore Alexandrescu“ dintre acestea: 7.444 de cazuri reprezentând $18,6 \%$ dintre acestea au fost reprezentate de infecțiile de tract respirator inferior. Etiologia virală a fost luată în discuție în 3.580 de cazuri reprezentând $8,9 \%$ din totalul de cazuri. Etiologia bacteriană a fost demonstrată în 3.864 din cazuri reprezentând $9,7 \%$ din total.

\section{Analiza datelor epidemiologice}

În perioada analizată 72 de copii cu vârsta sub 5 ani ce au prezentat semne de insuficiență respiratorie acută au avut stabilit un diagnostic etiologic concret de infecție virală, doar $2 \%$ din totalul infecțiilor virale. Etiologia principală a fost reprezentată de virusul sincițial respirator (VSR) în 73,5\% dintre cazuri, urmat de Influenza cu $11 \%$, Parainfluenza cu 4,2\%, Metapneumovirusul (HMPV), Rinovirus, Bocavirus şi Adenovirus toate cu 2,8\%.

Media de vârstă a fost de 1 an şi 2 luni, 70\% dintre cazuri au fost întâlnite la vârsta de sugar, 7,5\% dintre ele la nou-născuți. Virusurile sunt implicate cel mai frecvent în etiologia ITRI la copilul mic într-un procent de 30-67\%, acestea fiind cel mai frecvent întâlnite la sugari, unde produc forme severe de bronşiolita sau pneumonie complicate cel mai frecvent cu insuficiență respiratorie acută. (4)

Am comparat în continuare lotul de pacienți cu infecție virală specificată cu un lot de pacienți $(n=72)$ cu pneumonie bacteriană complicată cu insuficiență respiratorie. Vârsta medie a fost mai mare în lotul bacterian, de 2 ani şi 1 lună faţă de 1 an şi 2 luni în lotul viral ( $\mathrm{p}=0,0001)$, doar $35 \%$ din cazuri fiind prezente la sugari. Etiologia a putut fi stabilită într-o proporție de $30 \%$ din cazuri; ea a fost reprezentată de Streptoccocus Pneumoniae 14\%, urmată de Hemophilus Influenzae 11\%, Stafiloccocus aureus $3 \%$, Klebsiella pneumoniae 1\%. Frecvența germenilor implicați în ITRI de etiologie bacteriană concordă cu cea descrisă în literatură. În $70 \%$ din cazuri etiologia nu a putut fi precizată. Etiologia ITRI severă întâlnită în perioada studiată este cea descrisă în literatură cu predominanţa VSR şi a Streptoccocus Pneumoniae în infecțiile virale respectiv bacteriene ale sugarului şi copilului mic (7-9).

Am vrut să evaluăm dacă în loturile studiate wheezingul recurent se asociază mai frecvent infecției virale şi am constatat următoarele: în ambele loturi wheezingul recurent (definit ca mai mult de 2 episoade de wheezing în antecedente) a fost prezent în 64 de cazuri (44,4\%). Wheezingul recurent a fost prezent în antecedentele a $40(55 \%)$ dintre copiii cu infecție virală şi doar în 24 (33\%) dintre cazurile cu infecție bacteriană. În lotul nostru riscul de a dezvolta wheezing recurent la copiii cu infecție virală a fost de 1,5 ori mai mare (CI 95\%: 1,10-2,03) față 
Analiza datelor anamnestice şi clinice

\begin{tabular}{|l|c|c|c|c|c|c|}
\hline & $\begin{array}{c}\text { Nr. cazuri } \\
\text { N = 144 }\end{array}$ & $\begin{array}{c}\text { OR Infecția } \\
\text { virală }\end{array}$ & $\begin{array}{c}\text { OR Infecția } \\
\text { bacteriană }\end{array}$ & \multicolumn{2}{c|}{$\begin{array}{c}\text { Confidence } \\
\text { interval }\end{array}$} & P value \\
\hline Wheezing recurent & $64(45 \%)$ & 1,5 & - & 1,10 & 2,03 & $\mathrm{P}<0.05$ \\
\hline MPC & $38(26,4 \%)$ & 1,12 & - & 0,92 & 1,3 & $\mathrm{P}>0.05$ \\
\hline Prematuritate & $23(16 \%)$ & 1,87 & - & 0,8 & 4,1 & $\mathrm{P}>0.05$ \\
\hline$<6$ luni & $53(36,8 \%)$ & 1,45 & - & 1,12 & 1,89 & $\mathrm{P}<0.05$ \\
\hline SDA & $71(49,3 \%)$ & - & 1,08 & 0,7 & 1,5 & $\mathrm{P}>0.05$ \\
\hline Febra 39 ${ }^{\circ} \mathrm{C}$ & $53(36,8)$ & - & 1,45 & 1,12 & 1,89 & $\mathrm{P}<0.05$ \\
\hline Leucocitoza & $67(46,5)$ & - & 2 & 1,38 & 3 & $\mathrm{P}<0.05$ \\
\hline PCR & $69(47,9)$ & - & 2 & 1,36 & 2,92 & $\mathrm{P}<0.05$ \\
\hline $\begin{array}{l}\text { Portaj nazal } \\
\text { Pneumococ }\end{array}$ & $21(14 \%)$ & - & 3,2 & 1,23 & 8,27 & $\mathrm{P}<0.05$ \\
\hline
\end{tabular}

de cei cu infecție bacteriană rezultat ce a fost semnificativ statistic. Studiile din literatură corelează prezența infecției virale în perioada de sugar şi mai ales a infectiei severe cu VSR cu riscul de a dezvolta episoade recurente de wheezing şi astm bronşic. Există încă dezbateri în literatură despre relația de cauzalitate infecție virală - astm bronşic, fiind nevoie de mai multe studii longitudinale cu mai mulți copii pentru a stabili cu exactitate dacă infecția virală din copilărie este direct implicată în dezvoltarea astmului bronşic persistent (10).

Febra reprezintă un simptom important pentru diferențierea infecției virale de infecția bacteriană astfel că am analizat în continuare prezența febrei asociată simptomatologiei respiratorii şi am constat următoarele: riscul de a face febră în infecția bacteriană nu a fost mai mare față de infecția virală, însă febra cu temperatură peste $39{ }^{\circ} \mathrm{C}$ a fost mult mai frecvent întâlnită în cadrul infecției bacteriene $48 \%$ față de $25 \%$ riscul de a prezenta temperatură peste $39{ }^{\circ} \mathrm{C}$ în infecția bacteriană a fost de 1,45 de ori mai mare (CI 95\% 1,12-1,89), sugarii mici sub 6 luni au prezentat mult mai rar febră, şansa fiind de 1,7 ori mai mare pentru aceştia să nu prezinte febră (CI 95\% 1,23-2,39). Ghidurile de practică europene sugereză că o temperatură corporeală sub $38,5^{\circ} \mathrm{C}$, la un copil cu vârsta sub 5 ani şi simptomatologie sugestivă pentru pneumonie cu asocierea wheezingului în tabloul stetacustic ridică suspiciunea unei infecții virale. Rezultatele obținute confirmă ideea că o febră înaltă sugerează o infecție bacteriană însă simptomele trebuie evaluate cu multă atenție la sugarii mici, absența febrei la această grupă de vârstă nu exclude infecția bacteriană. (11)

\section{Analiza datelor paraclinice}

Leucocitoza cu neutrofilie a fost prezentă mai frecvent în cazurile cu infecție bacteriană, la fel s-a corelat pozitiv cu infecția bacteriană şi valoarea crescută a proteinei $\mathrm{C}$ reactive, astfel că şansa de a avea valori crescute ale PCR a fost de 2 ori mai mare în infecția bacteriana (CI 1,36-2,92). Rezultatele concordă cu rezultatele obținute în literatură, ultimele metaanalize sugerează că proteina $\mathrm{C}$ reactivă poate fi folosită pentru a diferenția între pneumonia virală şi pneumonia bacteriană. (12) Proteina C reactivă a fost crescută în $23 \%$ din cazurile cu infecție virală, iar din acestea mai ales în cadrul infecției cu VSR 24\% (p<0,05) şi gripă 62\% (p>0,05). Am constat că portajul nazal pneumococic a fost întâlnit în $21(14 \%)$ de cazuri, 22\% $(n=16)$ din infecțiile bacteriene şi $6 \%(n=5)$ din cele virale, riscul de a avea o infecție bacteriană fața de una virală a fost de 3,2 ori mai mare (CI 95\% 1,23-8,27). Intervalul de încredere arată un rezultat foarte semnificativ, acesta corelează cu discuțiile care se poartă în literatură despre colonizarea nazală pneumococică. Deşi nu este obligatoriu ca germenele evidențiat în exudatul nazal să fie implicat în etiologia pneumoniei, colonizarea reprezintă de fapt prima etapă a infecției invazive pneumococice şi joacă un rol esențial în răspândirea bacteriei în comunitate. (13)

\section{Analiza tratamentului şi a costurilor spitalizării}

Pentru analiza tratamentului şi a costurilor spitalizării am adăugat în discuție cel de-al treilea lot ce a însumat 62 de cazuri de copii între 0-5 ani, media de vârstă de 2 ani, cu infecție virală nespecificată (pneumonie sau bronşiolita) şi insuficiență respiratorie acută, lot pe care l-am comparat cu 62 de copii din lotul cu infecție virală specificată şi cu 62 de cazuri din lotul cu infecție bacteriană. Rezultatele au fost interesante, astfel: în cadrul infecției virale nespecificate s-au folosit antibiotice în 85,5\% $(n=53)$ din cazuri, asocierea a cel puțin 2 antibiotice fiind întâlnită în 3\% dintre cazuri. Antibioticele folosite au fost aminopeniciline 35\% dintre cazuri, cefalosporine $-48 \%$, generația a $2-a-24 \%$, generaţia a 3 a $-24 \%$, aminoglicozide $-1,5 \%$ şi macrolide $6 \%$ dintre cazuri.

În cadrul infecției virale specificate, deşi etiologia virală a fost certă, rata de folosire a antibioticelor a 
fost mai ridicată de $92 \%(n=57)$ lucru ce poate fi explicat prin media de vârsta mai mică a lotului viral specificat, media de vârstă de 1 an si 3 luni față de 2 ani, cu sugari în proporție de $70 \%$, şi sub 6 luni în proporție de $48 \%$, față de $30 \%$ respectiv $10 \%$. Aminopenicilinele au fost folosite în proporție de $53 \%$, cefalosporinele $-38 \%$, din care generatia a 3 a $-30 \%$, generatia a 2 a $-8 \%$, aminoglicozide $11 \%$, carbapeneme şi flurochinolone $-5 \%$, asocierea de cel puțin 2 antibiotice a fost întâlnită în $8 \%$ din cazuri. Rata de utilizare a antibioticelor este mare în ambele loturi acest lucru putând fi explicat bineînțeles de formele severe de boală ale copiilor incluşi în studiu şi de vârsta mică a acestora. Recomandările actuale sugereză că antibioticele nu ar trebui folosite în infecția virală dovedită decât dacă se suspicionează o infecție mixtă, însă anumiţi experți recomandă folosirea acestora în formele severe de boală deoarece suprainfecția bacteriană poate fi uneori greu de exclus. Un studiu important dublu orb randomizat placebo controlat a demonstrat însă că în cadrul infecției cu VSR antibioticele nu au fost eficiente în scurtarea evoluției bolii sau prevenirea apariției complicațiilor. (5)

În cadrul infectiei bacteriene antibioticele au fost folosite în toate cazurile $(n=62)$. Asocierea antibiotică a fost folosită în mai mult de $70 \%$ dintre cazuri $(p<0,05)$. Nevoia de utilizare a asocierii antibiotice în infecția bacteriană a fost de 2,9 ori mai mare decât în infecția virală (CI 95\% 1,98-4,25).

Durata spitalizării a fost în medie de 6,69 $\pm 3,6$ în cadrul lotului cu infecție virală specificată, cu un minim de 2 zile şi un maxim de 23 de zile. În cadrul lotului cu infecția virală nespecificată durata medie de spitalizare a fost de $4 \pm 1,74 \operatorname{minim} 1 \mathrm{zi}$, maxim 10 zile, iar în cadrul infecției bacteriene media de spitalizare a fost de 9,65 zile $\pm 3,3-$ minim 5 zile, maxim 20 zile. $(p<0,0001)$. Deşi etiologia virală a fost cunoscută şi spitalizarea a fost mai lungă cu 2 zile şi jumătate, acest lucru putând fi explicat de vârsta mică a copiilor şi forma severă de boală, este nevoie de un studiu prospectiv pe o durată mai lungă de timp care să evalueze cu exactitate cât de mult influențează cunoaşterea etiologiei virale durata spitalizării.

Cheltuielile cu spitalizarea au fost de $1.166 \pm$ 461 RON în medie pentru lotul cu infecție virală nespecificată, $1.542 \pm 522$ RON pentru lotul cu determinare virală şi $3.148 \pm 1.226 \mathrm{RON}$ pentru lotul cu infecție bacteriană. Astfel constatăm că, deşi diagnosticul de infecție virală a fost cert, dat fiind tabloul clinic sever şi vârsta mica a copiilor cheltuielile facute cu cei cu infecție virală specificată au fost cu 376 RON respectiv 30\% mai mari $(\mathrm{p}<0,0002)$. Pentru infecția bacteriană cheltuielile au fost aproape duble: $3.148 \pm 1.226 \mathrm{RON}$. Studiile din literatură arată date contradictorii legate de eficiența determinărilor virale în practică. În unele studii testele antigenice rapide au fost eficiente în reducerea spitalizărilor şi a ratei de prescriere a antibioticelor. Totodată, un studiu efectuat în cadrul unităţilor de primiri urgențe nu a demonstrat acest lucru, dovedind încă o dată că eficiența metodelor paraclinice de diagnosticare depinde foarte mult de locul în care acestea sunt folosite. (14-15). Ultimele studii controlate demonstrează că, deşi a diagnosticat mai multe tipuri de virusuri RT-PCR nu a redus nici numărul internărilor, nici durata spitalizării şi nici nu a limitat utilizarea antibioticelor. (16-17). Ghidurile actuale recomandă ferm utilizarea testelor de determinare virală pentru evidențierea virusului influenza, însă determinarea virală multiplă prin RT-PCR ar trebui folosită în practică numai dacă medicul clinician consideră că îşi va schimba atitudinea terapeutică. (18).

\section{CONCLUZII}

Deşi infecțiile respiratorii severe de etiologie virală reprezintă un procent important din totalul internărilor efectuate la copii mici, rata de diagnostic etiologic este încă foarte redusă pentru că metodele moderne de diagnostic de tip RT-PCR nu sunt încă la îndemâna medicului practician. În studiul nostru VSR este virusul cel mai frecvent implicat în etiologia ITRI virale, fiind implicat în forme severe de boală mai ales la sugarii mici şi foştii prematuri. Antibioterapia este utilizată în mod frecvent în formele severe de ITRI, chiar dacă etiologia virală este certă şi cunoscută, clasele de antibiotice folosite fiind asemănătoare. Determinarea etiologiei virale nu a redus spitalizarea şi nici nu a dus la schimbarea atitudinii terapeutice a medicului curant. Costurile spitalizării au fost mai mari la cei ce au beneficiat de determinări virale, însă au fost substanțial mai reduse față de cele întâlnite în ITRI de etiologie bacteriană. Deşi încă nu şi-au dovedit cu certitudine utilitatea în managementul clinic al copilului bolnav, determinarea etiologiei virale prin RT-PCR rămâne o unealtă importantă pentru mai buna înțelegere a etiologiei infecțiilor de tract respirator inferior al copilului şi se dovedeşte a avea un rol important în mai buna supraveghere a evoluției epidemiilor şi pentru limitarea extinderii infecțiilor intraspitaliceşti.

\section{Mențiune}

Această lucrare este efectuată în cadrul Programului Operațional Sectorial pentru Dezvoltarea Resurselor Umane (POSDRU), finanțat din Fondul Social European şi Guvernul României prin contractul nr: POSDRU/159/1.5/S/137390. 